DOI: https://doi.org/10.30525/978-9934-26-020-9-3

Tetiana Zakharova

Assistant of the Department of Foreign Economic Activity Management, Hotel and Restaurant Business and Tourism

Vinnytsia National Agricultural University

\title{
EFFICIENCY OF ACTIVITIES OF TOURISM OPERATORS AND AGENTS ON THE MARKET OF TOURIST SERVICES OF UKRAINE
}

\section{Summary}

In the sections the research of efficiency of activity of tourist operators and agents in the market of tourist services of Ukraine proceeding from dependence of cost of permits on volume of their realization to the population and quantity of the served tourists is carried out. The necessity to use such methods as correlation-regression analysis and adjusted least squares to evaluate the efficiency of these legal entities in the market of tourist services is substantiated. The method of analysis of the operating environment was used in the study of the positions of the regions of Ukraine where legal entities operate in the market of tourist services, which allowed travel agents and tour operators) to attract tourists and sell tourist vouchers to the population. The direction of development of the modern market of tourist services and according to it the direction of effective development of the market of tourist services of Ukraine owing to activity of travel agents is revealed. The necessity of maximum coincidence of these directions is proved, while for travel agents in the regions of Ukraine there is no such coincidence. It is proposed to change the positions of the regions where these entities operate in the effective direction of the operating environment by reducing the cost of vouchers and increasing tourist activity, as the study identified a number of areas where tourists pay higher vouchers than the national average. As a result of the analysis of the environment of operation of tour operators in the regions of Ukraine, a special position in the Kharkiv region was revealed, as one that allows to assess the effectiveness of these entities in all other regions of the country. A much larger organization in the market of tourist services of tour operators is proved in comparison with travel agents, as the positions in the respective oblasts are currently in the direction of effective development with the exception of Ternopil, Khmelnytsky and Chernivtsi oblasts. Conclusions are made on the need to develop all business entities in the market of travel services, in particular to provide benefits from the activities of travel agents. 


\section{Вступ}

Розвиток туризму в Україні є одним із найперспективніших напрямів соціально-економічного зростання, що може бути забезпечене активізацією діяльності та високою ефективністю суб'єктів ринку туристичних послуг. Особливої актуальності набуває дослідження ринку туристичних послуг у світлі того, що 2020 р. оголошено роком туризму в Україні.

Ефективний розвиток туризму вимагає встановлення та впровадження міжнародних стандартів, підвищення якості обслуговування й управління, що зменшить негативний плив зовнішніх чинників та сторонніх організацій. Сучасний стан формування та реалізації наявного туристичного потенціалу, з огляду на український ринок туристичних послуг, можна охарактеризувати як нерівномірний. Така ситуація зумовлена концентрацією на ринку туристичних послуг декількох атрактивних регіонів, передумови розвитку туризму у яких «лежать на поверхні», а власне місто є інфраструктурним центром і його огинання часто $\epsilon$ неможливим чи нелогічним у силу географічного та адміністративного розташування або ж у силу відповідно проведених маркетингових дій та їх результатів. Інша ситуація постає в малих та середніх містах, туристичний потенціал яких здебільшого є, безумовно, потужним, проте в силу географічної віддаленості, низького рівня інфраструктури та умов, що склалися історично, та подальших шляхів розвитку міста (за відповідним профілем: промисловим, науковим тощо) туристична сфера відійшла на другий план і не була вибрана ні джерелом економічного розвитку регіону, ні його частиною. Швидке зростання ролі туризму в національній економіці свідчить про активний розвиток даної сфери та актуальність їі активізації на території України. Діяльність юридичних осіб на ринку туристичних послуг в Україні представлена туристичними операторами (туроператорами) та туристичними агентствами (турагентствами). Туроператори $\epsilon$ безпосередньо виробниками туристичного продукту у вигляді створення туристичної послуги, забезпечення проїзду та проживання. Турагенти виконують функцію посередників між туроператором та споживачем. До основних завдань туроператорів можна віднести: вивчення потреб потенційних туристів на тури та туристичні програми, складання маршрутів та перспективних програм обслуговування туристів, взаємодію з постачальниками послуг, розрахунок вартості туру та визначення ціни, реалізацію турів, методичне забезпечення турів, забезпечення туристів необхідним та спеціальним спорядженням, сувенірною та рекламно-інформаційною продукцією, підготовку, підбір та призначення спеціалістів на маршрути подорожей (екскурсоводи, інструктори, гіди-перекладачі тощо), рекламно-інформаційну роботу щодо просування туристичного продукту до споживачів, контроль над якістю, надійністю та безпекою туристичного обслуговування. Їх мета 
полягає в отриманні комісійних за надання туристичної послуги на ринку. Окрім того, туроператори можуть працювати зі споживачем напряму без турагентів. Туроператори виконують провідну роль у туризмі, оскільки саме вони пакетують різні послуги (транспорт, розміщення, харчування, трансфер, розваги) в єдиний туристичний продукт, який і реалізують споживачеві через агентську мережу. Туроператор також може продавати послуги туризму роздільно. У разі коли туроператор формує туристичний пакет, він виступає в ролі виробника туристичного продукту. Це так, навіть якщо куплені послуги збираються використовувати конкретно за призначенням, без усяких умов.

Коли ж туроператор продає послуги туризму окремо, він виступає як оптовий дилер туристичних послуг. Це можливо в тому разі, коли туроператор купує у виробника більше туристичного продукту, ніж це необхідно для формування туристичного пакету. Бувають також випадки, коли туроператори продають окремі послуги туризму за гуртовими цінами людям, які формують свій індивідуальний пакет.

Туроператор укладає агентські угоди з незалежними турагентствами на продаж своїх турів, у яких він зацікавлений. Чим більше в туроператора партнерів-турагентів у різних країнах i регіонах, тим більші обсяги продажу і, відповідно, більше туристів, більший прибуток.

Необхідність розвитку туроперейтингу пов'язана, з одного боку, зі зростанням вимог туристів до змістовного проведення дозвілля, коли для повноцінного відпочинку недостатньо тільки розміщення та харчування, а потрібен цілий комплекс додаткових послуг відповідно до індивідуальних потреб туриста, а 3 іншого - зростання та урізноманітнення пропозиції послуг гостинності туристичних та курортних центрів, що ущільнює ринок пропозиції $\mathrm{i}$ потребує професійної зорієнтованості. Незалежно від особливостей діяльності туроператорів та турагентів головний принцип ефективного функціонування ринку туристичних послуг полягає у досягненні таких цілей: максимізація кількості туристів, що згодні здійснювати подорожі; максимізація обсягу реалізації населенню туристичних путівок; оптимізація вартості реалізованих населенню туристичних путівок.

\section{Розділ 1. Теоретико-методологічні засади формування стратегії комплексного розвитку суб'єктів туристичної сфери \\ та ефективність їх діяльності в умовах трансформаційних змін економіки України}

Науковці Kolosinska et al. (2018), Kovalov et al. (2017) [13; 14] досліджували теоретико-методологічні засади формування стратегії комплексного розвитку суб'єктів туристичної сфери та ефективність їх діяльності в умовах трансформаційних змін економіки України. Авторами Y. Kozak, T. Derkach, \& D. Huz [10] розглянуто компоненти стратегій забезпечення ефективності суб'єктів туристичної сфери, а 
саме: стратегія забезпечення економічної безпеки; фінансова стратегія; інвестиційна стратегія; інноваційна стратегія; інформаційна стратегія. T. But, T. Pulina, \& V. Zaytseva (2020), N. Shcherbakova (2018) визначають пріоритетні напрями реалізації стратегії розвитку ринку туристичних послуг в Україні: підвищення конкурентоспроможності регіонів та посилення їхнього ресурсного потенціалу, забезпечення розвитку людських ресурсів та міжрегіональної співпраці.

Багато науковців досліджували потенціал та конкурентоспроможність туризму в регіонах України. Y. Kovalchuk, I. Furman, H. Humenyuk, \& A. Kucher здійснили дослідження потенціалу та можливостей розвитку туристичної діяльності в регіонах України в сучасному контексті, використовуючи метод аналізу функціонуючого середовища. Авторами визнано, що дванадцять регіонів України мають високий потенціал розвитку туризму, але інші тринадцять не мали достатнього доходу від туристичних послуг для покриття витрат на оплату праці та експлуатації, що вказує на пошук нових методів у стратегічному та оперативному плануванні розвитку туризму в регіонах України та в підвищенні ефективності туристичного бізнесу [10]. В. Kovalov, I. Burlakova \& V. Voronenko встановили у своїх дослідженнях, що $y$ $88 \%$ регіонів України спостерігається позитивна тенденція зміни індексу конкурентоспроможності подорожей та туризму, що негативно впливає на ефективність діяльності туристичних операторів та агентів [13]. A. Mazaraki, M. Boiko, M. Bosovska, N. Vedmid \& A. Okhrimenko (2018) [5] наголошують у своїх дослідженнях на формуванні національної туристичної системи в Україні.

M. Kolosinska, O. Petrashchak, I. Kolosinskyi \& A. Katana запропонували методику оцінки конкурентоспроможності туризму, що вказала на значну кількість наявних позитивних чинників ефективного розвитку туризму. Позитивним моментом $\epsilon$ значний рівень конкуренції серед фірм-турагентів, наявність основних сегментів туристичного ринку, забезпечення туризму національними ресурсами. K. Sofiichuk дослідив теоретичну базу ризиків у туризмі, динаміку прибутків туристів та кількість туристичних підприємств, на основі чого розроблено модель управління ризиками в туризмі [11]. S. Ivanov, M. Gavrilina, C. Webster \& V. Ralko наголошують у своїх дослідженнях на негативному впливі політичної нестабільності на ефективність функціонування туристичної галузі [15].

Водночас, незважаючи на значну кількість досліджень у галузі туризму, залишається недостатньо вирішеною проблема економічної ефективності діяльності туристичних операторів та агентів на ринку туристичних послуг України.

Дослідження економічної ефективності туристичних операторів та агентів на ринку туристичних послуг України дали змогу виявити 
можливості зниження вартості туристичних путівок та збільшення обсягу реалізованих путівок та обслуговуваних туристів.

У дослідженні використовується комбінація параметричних та непараметричних методів аналізу, зокрема кореляційно-регресійний, метод аналізу середовища функціонування, метод коригованих найменших квадратів для побудови позицій областей України на ринку туристичних послуг, де здійснюють діяльність туристичні оператори та агенти.

Методика дослідження передбачала його реалізацію за таким алгоритмом:

1. Розрахунок коефіцієнтів віддачі вартості реалізованих населенню туристичних путівок турагентами та туроператорами за кількістю туристичних путівок та обслуговуваних туристів за регіонами України.

2. Проведення кореляційно-регресійного аналізу 3 виявлення залежності між віддачею вартості реалізованих населенню путівок турагентами та туроператорами за кількістю обслугованих туристів та віддачею вартості путівок за кількістю реалізованих населенню туристичних путівок, що дало змогу виявити високу щільність зв'язку між даними показниками.

3. Проведення аналізу середовища функціонування, що дало змогу виявити неможливість побудови лінії технічної ефективності по областях України для оцінки рівня неефективності на ринку туристичних послуг.

4. Здійснення аналізу за допомогою методу корегованих найменших квадратів, що дало змогу для оцінки областей за діяльністю турагентів побудувати лінію технічної ефективності, а по туроператорах обгрунтувати вплив на середовище функціонування позиції Харківської області.

5. Запропоновано заходи 3 підвищення ефективності діяльності турагентів відповідно до тенденцій сучасного розвитку ринку туристичних послуг.

6. Обгрунтовано достатність та закономірність розвитку туроператорів в областях України відповідно до тенденцій ринку туристичних послуг.

Розрахунок коефіцієнтів віддачі вартості реалізованих населенню туристичних путівок турагентами та туроператорами за кількістю туристичних путівок та обслуговуваних туристів за регіонами України дає нам можливість визначити важливі ключові моменти, які можуть вплинути на здатність підприємства досягати своїх цілей як у короткостроковій, так і в довгостроковій перспективі. За допомогою проведення кореляційно-регресійного аналізу готується комплексний план розвитку підприємств туристичної галузі, здійснюється науково обгрунтована, всебічна i своєчасна підтримка прийняття вірних управлінських рішень. Аналіз внутрішнього середовища допоміг визначити сукупність чинників ефективної діяльності туристичних 
операторів та агентів на ринку туристичних послуг України, що зумовлений реалізацію основних функцій, зокрема в аспектах надання основних послуг. Однак для підприємств туризму як відкритої системи не менш суттєвим $є$ розуміння перебігу не лише внутрішніх структурнофункціональних процесів, а й усвідомлення змісту та характеру зовнішніх подій і явищ, що, власне, становлять структуру зовнішнього середовища його функціонування. Саме тому аналіз зовнішнього середовища має на меті виділення чинників, які найбільшою мірою впливають на успіх або невдачу діяльності підприємства, а також постійний моніторинг їх змісту та стану задля передбачення можливих змін у майбутньому.

Суттєвий внесок у розвиток підходу суспільних вигід та витрат зробив К. Блейк [19], який запропонував власну класифікацію інвестиційних проєктів, згідно з якою усі проєкти, що реалізуються у регіоні, слід поділити на три категорії:

1. subsidy-diverted projects - за відмови від реалізації заходів регіональної інвестиційної політики були б реалізовані в інших регіонах;

2. autonomous projects - за відмови від реалізації заходів регіональної інвестиційної політики у будь-якому разі були б реалізовані у субсидійованому регіоні;

3. subsidy-created projects - за відмови від реалізації заходів регіональної інвестиційної політики не будуть реалізовані в жодному регіоні.

К. Блейк відзначав, що автономні проєкти не повинні враховуватися під час оцінювання ефективності регіональної інвестиційної політики ні з боку вигід, ні з боку витрат.

Практична реалізація методу вигід та витрат в Україні виглядає доволі проблематичною через його досить велику його вартість. Справа в тому, що для повноцінного впровадження цієї методики необхідна детальна інформація про умови розроблення та реалізації основних туристичних інвестиційних проєктів регіону, системи їх державного стимулювання та заходів організаційної підтримки. Важливою $є$ також інформація про реакцію економічних агентів на систему стимулів, яку пропонує місцева адміністрація. Отримання хоча б наближеної інформації стосовно діючих у регіоні інвестиційних проєктів передбачає проведення надзвичайно вартісних досліджень, що робить такий метод непрактичним та нерентабельним в умовах сучасної України.

Альтернативою методу вигід та витрат може бути використання методів, які грунтуються на порівнянні ефективностей різних регіонів. Прикладом такого підходу є так званий DEA (Data envelopment analysis) аналіз, уперше запропонований американськими дослідниками А. Чарнезом, Е. Роудом та У. Купером, які використали ідеї, викладені нобелівським лауреатом Ж. Дебрѐ у праці The coefficient of resource utilization [19] та англійцем М. Фаррелом у статті The measurement of 
Productive Efficiency [2]. Сьогодні DEA-аналіз став популярним інструментом оцінювання ефективності, і різноманітні варіанти цієї моделі знайшли своє застосування у багатьох сферах економіки та бізнесу як засіб визначення відносної ефективності одиниць прийняття рішення DMUs (decision making units) на основі їх входів та виходів.

\section{Розділ 2. Схема розрахунку коефіціснтів віддачі вартості реалізованих населенню туристичних путівок турагентами та туроператорами за кількістю туристичних путівок та обслуговуваних туристів}

Метод аналізу середовища функціонування (модель Фаррелла) [2] є найбільш прийнятним методом оцінювання ефективності функціонування юридичних осіб на ринку надання туристичних послуг. У нашому випадку пропонуємо використати схему розрахунку коефіцієнтів віддачі вартості реалізованих населенню туристичних путівок турагентами та туроператорами за кількістю туристичних путівок та обслуговуваних туристів (табл. 1) аналогічно прикладу Фаррелла щодо співвідношення капіталу та витрат на оплату праці 3 обсягом реалізованої продукції.

Початково модель Фаррелла використовувалася для розрахунку ефективності суб'єктів господарювання в умовах природного монополізму, однак подальші вдосконалення дали змогу більш широко іiі використовувати у маркетингових дослідженнях. Особливість методу аналізу середовища функціонування полягає у його універсальності, що дає змогу використовувати його принципи для різних галузей народного господарства, видів економічної діяльності незалежно від досліджуваних показників [4-6; 8; 16; 17]. H. Horban, I. Petrovska, A. Kucher, A. Diuk (2020) використали даний метод для дослідження ефективності функціонування туристичних суб'єктів у регіонах України.

Таким чином, $\mathrm{X}_{1}$ - кількість туристів, обслугованих турагентами або туроператорами по Україні за 2018 р.

$\mathrm{X}_{2}$ - кількість реалізованих населенню туристичних путівок турагентами або туроператорами по Україні за 2018 р.

Y - вартість реалізованих населенню туристичних путівок турагентами або туроператорами по Україні (тис грн) за 2018 р.

Коефіцієнти розраховано на основі даних Державної служби статистики України [1] щодо туристичної діяльності в Україні в 2018 р.

Виходячи 3 результатів табл. 1 по турагентах, побудуємо згідно 3 моделлю Фаррелла середовище функціонування цих суб'єктів господарювання та визначимо напрям розвитку щодо залучення туристів та реалізації туристичних путівок населенню за 2018 р. по регіонах України (рис. 1). 
Таблиця 1

Коефіцієнти віддачі вартості реалізованих населенню туристичних путівок турагентами та туроператорами за кількістю туристичних путівок та обслуговуваних туристів за регіонами України у 2018 р.

(кількість туристичних путівок та обслуговуваних туристів на 1000 грн вартості реалізованих населенню туристичних путівок)

\begin{tabular}{|l|c|c|c|c|}
\hline \multirow{2}{*}{ Область } & \multicolumn{2}{|c|}{ Турагенти } & \multicolumn{2}{c|}{ Туроператори } \\
\cline { 2 - 5 } & $\mathbf{X}_{\mathbf{1}} / \mathbf{Y}$ & $\mathbf{X}_{\mathbf{2}} / \mathbf{Y}$ & $\mathbf{X}_{\mathbf{1}} / \mathbf{Y}$ & $\mathbf{X}_{\mathbf{2}} / \mathbf{Y}$ \\
\hline Вінницька & 0,127 & 0,071 & 0,442 & 0,231 \\
\hline Волинська & 0,08 & 0,047 & 0,188 & 0,119 \\
\hline Дніпропетровська & 0,061 & 0,034 & 0,06 & 0,047 \\
\hline Донецька & 0,105 & 0,074 & 0,153 & 0,089 \\
\hline Житомирська & 0,086 & 0,053 & 0,799 & 0,246 \\
\hline Закарпатська & 0,066 & 0,037 & 0,264 & 0,128 \\
\hline Запорізька & 0,078 & 0,042 & 0,218 & 0,14 \\
\hline Івано-Франківська & 0,094 & 0,056 & 0,13 & 0,128 \\
\hline Київська & 0,072 & 0,032 & 0,047 & 0,022 \\
\hline Кіровоградська & 0,076 & 0,039 & - & - \\
\hline Луганська & 0,184 & 0,174 & - & - \\
\hline Львівська & 0,082 & 0,069 & 0,094 & 0,249 \\
\hline Миколаївська & 0,054 & 0,036 & 0,076 & 0,05 \\
\hline Одеська & 0,056 & 0,038 & 0,212 & 0,205 \\
\hline Полтавська & 0,06 & 0,041 & - & - \\
\hline Рівненська & 0,07 & 0,042 & 0,069 & 0,069 \\
\hline Сумська & 0,077 & 0,048 & 0,06 & 0,051 \\
\hline Тернопільська & 0,073 & 0,037 & 1,192 & 0,627 \\
\hline Харківська & 0,072 & 0,044 & 0,016 & 0,013 \\
\hline Херсонська & 0,151 & 0,13 & 0,231 & 0,231 \\
\hline Хмельницька & 0,122 & 0,085 & 1,286 & 1,286 \\
\hline Черкаська & 0,076 & 0,033 & 0,104 & 0,059 \\
\hline Чернівецька & 0,101 & 0,042 & 0,564 & 0,278 \\
\hline Чернігівська & 0,061 & 0,03 & 0,093 & 0,036 \\
\hline м. Київ & 0,1 & 0,046 & 0,086 & 0,04 \\
\hline
\end{tabular}

Провівши кореляційно-регресійний аналіз, виявлено високу щільність зв'язку (коефіцієнт кореляції дорівнює 0,93). Рівняння регресії $\mathrm{y}=-0,031+0,9867 \mathrm{x}\left(\mathrm{x}=\mathrm{X}_{1} / \mathrm{Y}\right)$ свідчить, що умовою досягнення нуля $\left(\mathrm{y}=\mathrm{X}_{2} / \mathrm{Y}=0\right) \in \mathrm{x}=0,0314$

Разом із тим, виходячи 3 особливостей лінії тренду та рівняння регресії, неможливо визначити позиції, що забезпечують ефективність функціонування туристичного ринку України та напрями його подальшого розвитку, оскільки значення 0,0314 може бути досягнуто безліччю комбінацій між кількістю туристів, обслугованих тур агентами, та вартістю реалізованих населенню туристичних путівок турагентами. Більше того, продовження лінії регресії дає змогу визначити межі іiі 
перетину з віссю абсцис та перпендикуляром із позиції 11 (Луганська область), що характеризують неефективність функціонування суб'єктів господарювання на ринку туристичних послуг, а граничні обмеження параметричної залежності $\mathrm{X}_{2} /$ Y від $\mathrm{X}_{1} / \mathrm{Y}$.

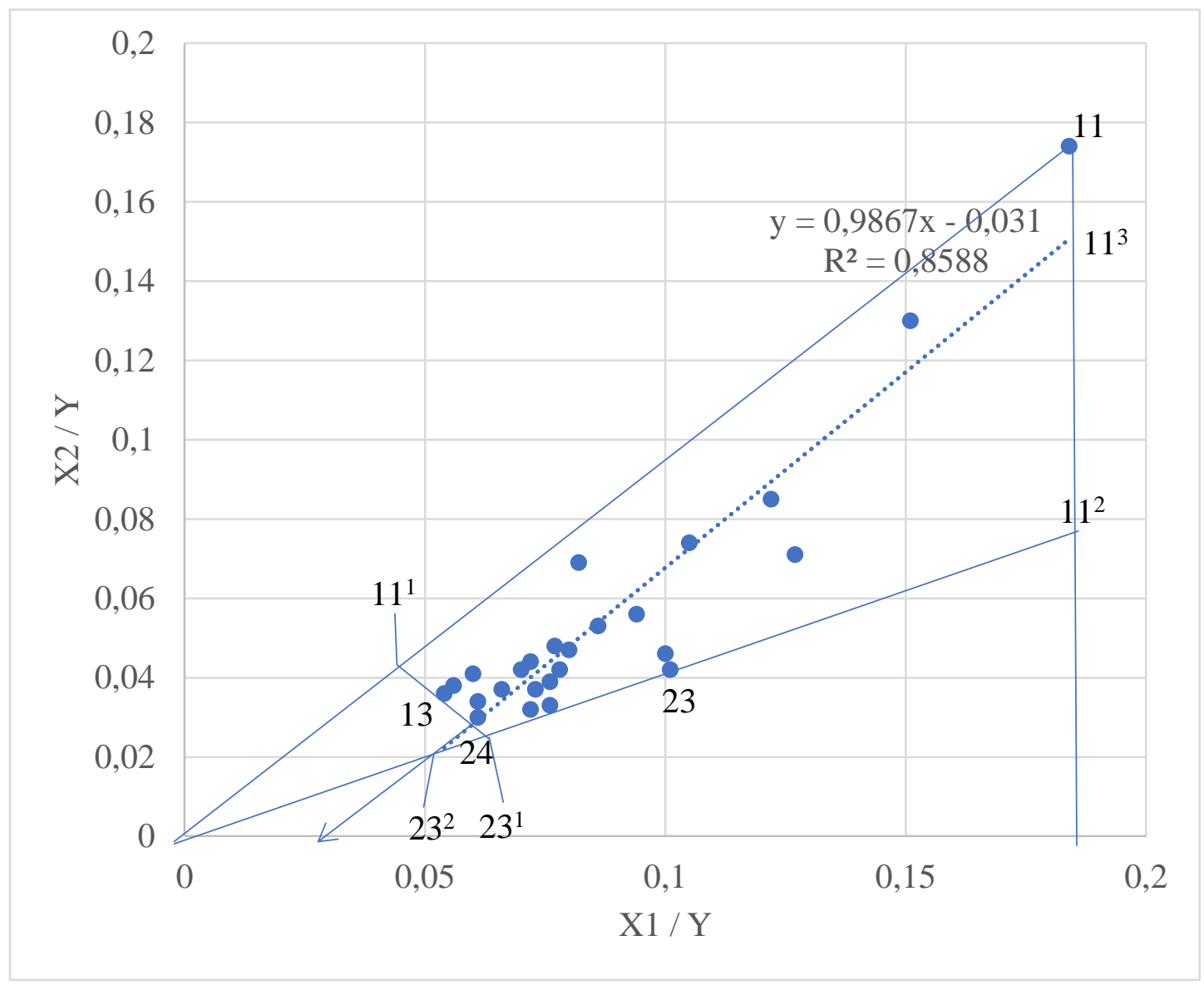

Рис. 1. Визначення напряму розвитку діяльності юридичних осіб (турагентів) щодо залучення туристів та реалізації туристичних путівок населенню за 2018 р. по регіонах України

Окрім того, висока щільність зв'язку не дає змоги повноцінно застосувати метод аналізу середовища функціонування, оскільки спостерігається лише дві позиції, що можуть скласти лінію технічної ефективності - 13 (Миколаївська область) та 24 (Чернігівська область). Ураховуючи вищезазначені параметри, пропонуємо спроєктувати лінію технічної ефективності шляхом застосування методу корегованих найменших квадратів.

Для цього проведемо дві лінії з початку координат, що проходять через позиції областей мінімального значення (23 - Чернівецька область) та максимального значення (11 - Луганська область). Таким чином, трикутник $0-11-11^{2} \epsilon$ напрямом розвитку сучасного ринку 
туристичних послуг України за 2018 р. Тенденція цього розвитку спрямована на початок координат, що свідчить про можливості зменшення вартості туристичних путівок.

Якщо продовжити відрізок лінії технічної ефективності (довжина 13-24) до перетину з лініями $0-11$ та $0-11^{2}$, то отримаємо гіпотетичну лінію технічної ефективності $11^{1}-13-24-23^{1}$. Відповідно, трикутник $0-11^{1}-23^{1} є$ напрямом ефективного розвитку ринку туристичних послуг України за 2018 р. Тенденція досягнення ефективності спрямована на початок координат - збільшення кількості туристів, обсягу реалізованих путівок турагентами, причому звуження простору біля початку координат свідчить про «спрямовану ефективність», де може йтися не про лінію технічної ефективності (у даному разі iї існування $\epsilon$ проєктним розрахунком на майбутнє), а напрям до нуля (зменшення вартості путівок). Як наслідок, замість лінії технічної ефективності може використовуватися позиція області, що $є$ технічно ефективною для інших регіонів України у разі їі знаходження біля початку координат.

Лінія тренду дає змогу в сукупності 3 двома граничними лініями проаналізувати позиції областей України щодо діяльності турагентів на ринку туристичних послуг у межах площ $11^{1}-11-11^{3}-24$ та $23^{2}-11^{2}-11^{3}$. Зазначимо позицію 11 (Луганська область) як певний виняток, що пояснює особливості становища на всьому ринку. У цій області найнижча вартість туристичних путівок, однак менше всього їх було реалізовано населенню та відправлено туристів.

Позиції областей, що знаходяться у межах площі $11^{1}-11-11^{3}-24$ - це області, де путівки купуються за вищою вартістю порівняно 3 усією Україною та в яких обслуговується більшість туристів: Дніпропетровська, Донецька, Закарпатська, Львівська, Одеська, Полтавська, Рівненська, Сумська, Харківська, Херсонська. Позиції областей, що знаходяться у межах площі $23^{2}-11^{2}-11^{3}$, - це області, де, навпаки, путівки купуються за нижчою вартістю порівняно з усією Україною та в яких обслуговується менше туристів.

\section{Розділ 3. Визначення напряму розвитку щодо залучення туристів та реалізації туристичних путівок населенню}

Світові стандарти туризму вже давно відійшли від рівня уніфікованих, середніх. Актуальним сьогодні став так званий програмний туризм, або програмний туроперейтинг. Це необхідність сьогоднішнього туристичного ринку, що витікає з жорсткої і в переважно нецінової конкуренції, існуючої на туристському ринку. Причому йдеться про конкуренцію не лише підприємницьку, а й регіональну. Можна також поговорити і про конкурентну боротьбу за свого клієнта, а саме: щоб притягнути туристів в Україну, необхідно підготувати програми й умови обслуговування такого ж рівня, а в чомусь і оригінальніші, ніж міжнародні зразки. Для цього треба, по-перше, знати, як це вже робиться, які існують традиції, 
норми і туристські пристрасті у цій сфері; по-друге, уміти застосовувати ці знання для розроблення власних програм обслуговування, власного комплексу рецептивного туроперейтинга.

Сучасна структура ринку організованого туризму характеризується як часткова олігополія. Найбільші туроператори (як правило, це 3-6 фірм) контролюють $40-60 \%$ ринку. У сучасних умовах європейський ринок туроператорів характеризують такі тенденції:

- падіння темпів зростання попиту на турпослуги і стагнація попиту на високому рівні;

- частка організованого туризму в загальному обсязі ринку вже декілька років не росте;

- постійно збільшується число туроператорів;

- споживач туристських послуг став більш вимогливим як відносно якості, так і відносно ціни;

- посилення конкурентної боротьби на ринку організованого туризму;

- вихід на ринок зарубіжних конкурентів;

- активне впровадження авіакомпаній на ринок туризму як туроператорів;

- тенденція до подолання розподілу праці між туроператорами $\mathrm{i}$ турагентствами (наприклад, упровадження міжнародних електронних систем резервування місць, прагнення турагентств до самостійної організації турів за допомогою цих систем).

Діяльність туроператора та турагента - це закономірне (яке пояснюється чинниками сезонності, динамікою ринкової кон'юнктури, специфікою роботи постачальників туристичного продукту) об'єднання (яке має на увазі послідовну зміну i/або паралельність) робочих циклів туроператора по конкретних турах або програмах.

Як по турагентах, так і по туроператорах (табл. 1) побудуємо згідно 3 моделлю Фаррелла середовище функціонування цих суб'єктів господарювання та визначимо напрям розвитку щодо залучення туристів та реалізації туристичних путівок населенню за 2018 р. по регіонах України (рис. 2).

Харківська область (позиція 19) $є$ технічно ефективною по відношенню до всіх регіонів України, у яких здійснюють діяльність туроператори. Привертає увагу висока щільність позицій областей у трикутнику 19 (Харківська область) - 12 (Львівська область) 5 (Житомирська область), що визначає напрям розвитку сучасного ринку туристичних послуг України за 2018 р.

Таким чином можна зробити висновок про відсутність напряму ефективного розвитку ринку туристичних послуг України, оскільки позиція 19 (Харківська область) максимально наближена до початку координат. Діяльність туроператорів на вітчизняному ринку туристичних послуг $\epsilon$ гарантуванням розвитку та ефективного забезпечення оптимальної вартості путівок та максимального залучення туристів. 


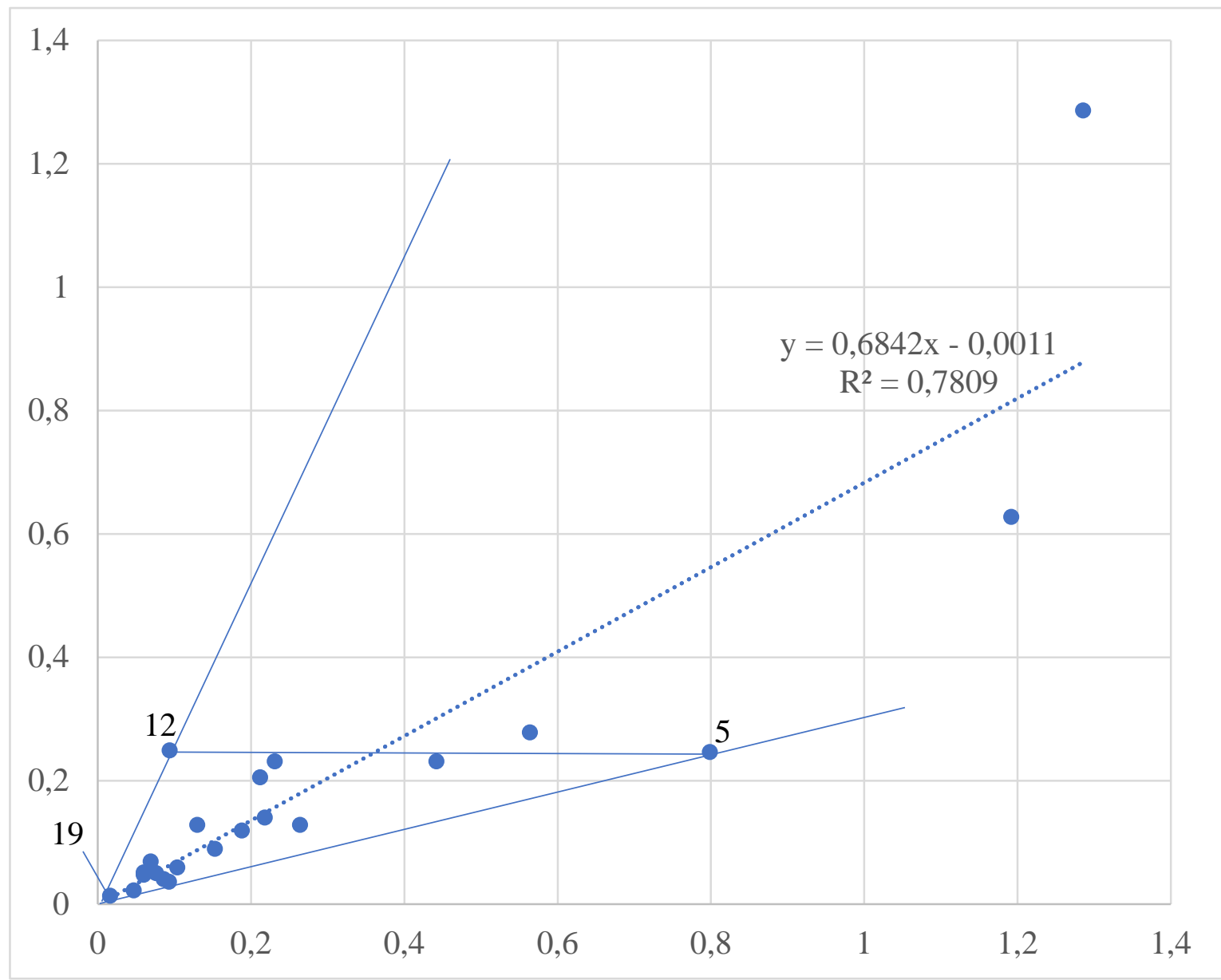

Рис. 2. Визначення напряму розвитку діяльності юридичних осіб (туроператорів) щодо залучення туристів та реалізації туристичних путівок населенню за 2018 р. по регіонах України

Виняток становлять лише три області, що знаходяться за межами площі трикутника 19-12-5: Тернопільська, Хмельницька, Чернівецька.

\section{Висновки}

Розвиток ринку туристичних послуг у регіонах України відбувається переважно завдяки діяльності туроператорів, що дає змогу значно здешевлювати вартість путівок та залучати нових клієнтів, тому тенденції розвитку ринку туристичних послуг щодо діяльності туроператорів співпадають із тенденціями ефективного функціонування їх в областях держави.

Діяльність турагентів на ринку туристичних послуг України не $є$ оптимальною. Сьогодні економісти не дійшли спільної думки: проходимо ми $\mathrm{U}$ - чи $\mathrm{W}$-подібне падіння економіки з подальшим відновленням. Те ж саме ми спостерігаємо й у діяльності туроператорів. Дослідження показали, що в сучасних умовах туроператори працюватимуть у режимі короткострокового гнучкого планування, пошуку нових моделей роботи, можливостей оптимізації, розроблення нових продуктів і пропозицій. 
У результаті дослідження запропоновано поліпшені позиції щодо їх функціонування по окремих регіонах, зокрема Луганської області (дві позиції) та Чернівецької області (дві позиції). Окреслено напрям розвитку сучасного ринку туристичних послуг України виходячи 3 можливості досягнення ефективності функціонування турагентів через зменшення вартості путівок та збільшення кількості туристів. Удосконалення цінової політики туристичних підприємств передбачає необхідність якісно нового підходу до ціноутворення, який забезпечить підвищення ефективності діяльності туристичних підприємств, досягнення довгострокових конкурентних переваг на туристичному ринку. У зв'язку із цим у сучасних умовах виникає потреба у застосуванні туристичними підприємствами процесного підходу як до формування цінової політики у цілому, так і до окремих його етапів. При цьому прийняття стратегічних цінових рішень та забезпечення їх обгрунтованості сприятимуть підвищенню ефективності діяльності та зміцненню ринкових позицій туристичних підприємств. Реалізація стратегічних рішень турагентів неможлива без формування ефективної політики ціноутворення в системі реалізації туристичного продукту. Поєднання дій туроператорів та турагентів у напрямі формування ефективної системи реалізації туристичного продукту дасть змогу вирішити питання, пов'язані 3 можливістю максимального задоволення потреб кінцевого споживача та забезпечення дотримання економічних інтересів усіх учасників системи реалізації туристичного продукту. Результати досліджень можуть бути використані під час планування діяльності туристичних операторів та агентів на ринку туристичних послуг України.

\section{Список використаних джерел:}

1. Головне управління статистики у Вінницькій області. URL: http://www.vn.ukrstat.gov.ua/

2. Farrell M.J. (1957) The Measurement of Productive Efficiency. Journal of Royal Statistical Society, Series A, CXX, part 3, pp. 253-290.

3. But, T., Pulina, T., \& Zaytseva, V. (2020) Justification of Ukraine’s tourist services development strategy. Management and Entrepreneurship: Trends of Development, № 1(11). P. 23-40. DOI: https://doi.org/10.26661/2522-1566/2020-1/11-02

4. Evaluation of the Efficiency of Enterprises by the Method of Analysis of Functioning Environment (2019) / A. Sakhno et al. Journal of Environmental Management and Tourism. Vol. X. № 3(35). P. 499-507. DOI: 10.14505/jemt.v10.3(35).04

5. Methodology for the Impact Assessment of the Digital Economy on Agriculture Development (2019) / A. Sakhno et al. International Journal of Recent Technology and Engineering. Vol. 8. Issue 3C. P. 160-164. DOI: 10.35940/ijrte.C1027.1183C19

6. Efficiency of managing liabilities of enterprises of different types of economic activities (2020) / A. Sakhno et al. European Journal of Sustainable Development. № 9(1). P. 423-423. DOI: 10.14207/ejsd.2020.v9n1p423

7. Formation of the national tourism system of Ukraine (2018) / A. Mazaraki et al. Problems and Perspectives in Management. № 16(1). P. 68-84. URL: http://dx.doi.org/ 10.21511/ppm.16(1).2018.07 
8. Mortgage lending system of agricultural enterprises of Ukraine (2020) / A. Sakhno et al. Revista Espacios. № 1015. Vol. 41(15). P. 7.

9. Potential And Opportunities for Development of Tourism in Ukraine (2020) / Y. Kovalchuk et al. Journal of Environmental Management and Tourism. № 11(1). P. 194-201. URL: https://doi.org/10.14505//jemt.v11.1(41).22

10. Kozak, Y., Derkach, T., \& Huz, D. (2019). Forming the strategy of integrated development of tourism enterprises. Baltic Journal of Economic Studies. № 5(4). P. 105-115. URL: https://doi.org/10.30525/2256-0742/2019-5-4-105-115

11. Sofiichuk, K. (2018). Risks of the tourism industry in Ukraine. Journal of Environmental Management and Tourism (JEMT). № 9(26). P. 334-342. DOI: https://doi.org/10.14505//jemt.9.2(26).15

12. Shcherbakova, N. (2018). State and Trends of Sustainable Development of Tourism in Ukraine and the World. Journal of Environmental Management and Tourism (JEMT). № 9 (08(32)). P. 1712-1724. DOI: https://doi.org/10.14505//jemt.v9.8(32).10

13. Kovalov, B., Burlakova, I., \& Voronenko, V. (2017). Evaluation of Tourism Competitiveness of Ukraine's Regions. Journal of Environmental Management \& Tourism. № 8 (2(18)). P. 460. DOI: https://doi.org/10.14505//jemt.v8.2(18).19

14. Tourism sector in transition economy on example of Ukraine: determinants of competitiveness (2018) / M. Kolosinska et al. GeoJournal of Tourism and Geosites. № 21(1). P. 239-252. URL: https://doi.org/10.30892/gtg.21119-284

15. Impacts of political instability on the tourism industry in Ukraine (2017) / S. Ivanov et al. Journal of Policy Research in Tourism, Leisure and Events. № 9(1). P. 100-127. URL: https://doi.org/10.1080/19407963.2016.1209677

16. A methodological analysis for the impact assessment of the digitalisation of economy on agricultural growth. International (2020) / A. Sakhno et al. Journal of Advanced Science and Technology. Vol. 29. № 8s(2020). P. 242-249.

17. Impact of Credit and Investment Resources on the Productivity of Agricultural Sector (2019) / A. Sakhno et al. European Journal of Sustainable Development. № 8(2). P. 335-345. DOI: 10.14207/ejsd.2019.v8n2p335

18. Efficiency of Tourism Activities in Ukraine: A Regional Comparison (20202) / H. Horban et al. Journal of Environmental Management and Tourism. Volume XI, Summer. № 4(44). P. 874-882. DOI:10.14505/11.4(44).11

19. Blake C. (1973) The gains from regional policy. J.N. Wolfe (Ed.), Costbenefit and cost effectiveness, Unwin, London, P. 185-194.

20. Cooper, W.W., Seiford, L.M. \& Tone, K. (2006). Introduction to Data Envelopment Analysis and Its Uses. New York : Springer. DOI: 10.1007/0-387-29122

\section{References:}

1. Official site of the State Statistics Service of Ukraine. Available at: http://www.ukrstat.gov.ua

2. Farrell M. J. (1957) The Measurement of Productive Efficiency. Journal of Royal Statistical Society, Series A, CXX. Part 3, pp. 253-290.

3. But, T., Pulina, T., \& Zaytseva, V. (2020). Justification of Ukraine's tourist services development strategy. Management and Entrepreneurship: Trends of Development, 1(11), 23-40. DOI: https://doi.org/10.26661/2522-1566/2020-1/11-02

4. Sakhno A., Hryvkivska O., Salkova I., Kucher L. Evaluation of the Efficiency of Enterprises by the Method of Analysis of Functioning Environment (2019), Journal of Environmental Management and Tourism, Vol. X, 3(35), pp. 499-507. DOI:10.14505/jemt.v10.3(35).04

5. Sakhno A., Salkova I., Broyaka A., Priamukhina N. (2019). Methodology for the Impact Assessment of the Digital Economy on Agriculture Development. International 
Journal of Recent Technology and Engineering, Volume-8, Issue 3C, 160-164. DOI:10.35940/ijrte.C1027.1183C19

6. Sakhno A., Salkova I., Polishchuk N., Kucher L. Stashko I. (2020) Efficiency of managing liabilities of enterprises of different types of economic activities. European Journal of Sustainable Development, 9 (1), pp. 423-423 DOI: 10.14207/ ejsd.2020.v9n1p423

7. Mazaraki, A., Boiko, M., Bosovska, M., Vedmid, N., \& Okhrimenko, A. (2018). Formation of the national tourism system of Ukraine. Problems and Perspectives in Management, 16(1), 68-84. http://dx.doi.org/10.21511/ppm.16(1).2018.07

8. Sakhno A. A., Polishchuk N. V., Salkova I. Y., Kucher L. Y. \& Kudyrko O. M. (2020). Mortgage lending system of agricultural enterprises of Ukraine. Revista Espacios, 1015 Vol. 41(15), pp. 7.

9. Kovalchuk Y., Furman I., Humenyuk H., \& Kucher A. (2020). Potential And Opportunities for Development of Tourism in Ukraine. Journal of Environmental Management and Tourism, 11(1), pp. 194-201. https://doi.org/10.14505//jemt.v11.1(41).22

10. Kozak, Y., Derkach, T., \& Huz, D. (2019). Forming the strategy of integrated development of tourism enterprises. Baltic Journal of Economic Studies, 5(4), 105-115. https://doi.org/10.30525/2256-0742/2019-5-4-105-115

11. Sofiichuk, K. (2018). Risks of the tourism industry in Ukraine. Journal of Environmental Management and Tourism (JEMT), 9(26), 334-342. DOI: https://doi.org/ 10.14505//jemt.9.2(26).15

12. Shcherbakova, N. (2018). State and Trends of Sustainable Development of Tourism in Ukraine and the World. Journal of Environmental Management and Tourism (JEMT), 9(08 (32)), 1712-1724. DOI: https://doi.org/10.14505//jemt.v9.8(32).10

13. Kovalov, B., Burlakova, I., \& Voronenko, V. (2017). Evaluation of Tourism Competitiveness of Ukraine's Regions. Journal of Environmental Management \& Tourism, 8 (2(18)), 460. DOI: https://doi.org/10.14505//jemt.v8.2(18).19

14. Kolosinska, M., Petrashchak, O., Kolosinskyi, I., \& Katana, A., (2018). Tourism sector in transition economy on example of Ukraine: determinants of competitiveness. GeoJournal of Tourism and Geosites, 21(1), 239-252. https://doi.org/10.30892/gtg.21119-284

15. Ivanov, S., Gavrilina, M., Webster, C., \& Ralko, V. (2017). Impacts of political instability on the tourism industry in Ukraine. Journal of Policy Research in Tourism, Leisure and Events, 9(1), 100-127. https://doi.org/10.1080/19407963.2016.1209677

16. Sakhno A., Salkova I., Broyaka A., Priamukhina N. (2020). A methodological analysis for the impact assessment of the digitalisation of economy on agricultural growth. International Journal of Advanced Science and Technology, Vol. 29, No. 8s, (2020), pp. 242-249

17. Sakhno A., Polishchuk N., Salkova I., Kucher A. (2019) Impact of Credit and Investment Resources on the Productivity of Agricultural Sector. European Journal of Sustainable Development. 8(2), pp. 335-345. DOI: 10.14207/ejsd.2019.v8n2p335

18. Horban, H., Petrovska, I., Kucher, A., Diuk, A. (2020). Efficiency of Tourism Activities in Ukraine: A Regional Comparison. Journal of Environmental Management and Tourism, (Volume XI, Summer), 4(44): 874-882. DOI:10.14505/11.4(44).11

19. Blake C. (1973) The gains from regional policy. J.N. Wolfe (Ed.), Costbenefit and cost effectiveness, Unwin, London, pp. 185-194.

20. Cooper, W. W., Seiford, L. M. \& Tone, K. (2006). Introduction to Data Envelopment Analysis and Its Uses. New York: Springer. DOI 10.1007/0-387-29122 